\title{
$\mathrm{Li}\left(\mathrm{Ni}_{1-x-y} \mathrm{Co}_{x} \mathrm{Mn}_{y}\right) \mathrm{O}_{2}$ 계 이차전지 공정 스크랩으로부터 회수한 전이금속을 활용한 리튬이차전지 양극재 제조
}

\author{
이재원 ${ }^{*} \cdot$ 김대원 $^{a} \cdot$ 장성태 $^{a}$ \\ 단국대학교 에너지공학과, ${ }^{a}$ (주)타운마이닝캄파니
}

\section{Preparation of Cathode Materials for Lithium Rechargeable Batteries using Transition Metals Recycled from $\mathrm{Li}\left(\mathrm{Ni}_{1-\mathrm{x}-\mathrm{y}} \mathrm{Co}_{\mathrm{x}} \mathrm{Mn}_{\mathrm{y}}\right) \mathrm{O}_{2}$ Secondary Battery Scraps}

\author{
Jae-won Lee*, Dae Weon Kim ${ }^{a}$, and Seong Tae Jang ${ }^{a}$ \\ Department of Energy Engineering, Dankook University, Cheonan, Korea \\ ${ }^{a}$ Townmining Company Ltd., Kumi, Korea
}

(Received April 10, 2014; Revised April 21, 2014; Accepted April 21, 2014)

\begin{abstract}
Cathode materials and their precursors are prepared with transition metal solutions recycled from the the waste lithium-ion batteries containing NCM (nickel-cobalt-manganese) cathodes by a $\mathrm{H}_{2}$ and C-reduction process. The recycled transition metal sulfate solutions are used in a co-precipitation process in a CSTR reactor to obtain the transition metal hydroxide. The $\mathrm{NCM}$ cathode materials $(\mathrm{Ni}: \mathrm{Mn}: \mathrm{Co}=5: 3: 2)$ are prepared from the transition metal hydroxide by calcining with lithium carbonate. X-ray diffraction and scanning electron microscopy analyses show that the cathode material has a layered structure and particle size of about $10 \mu \mathrm{m}$. The cathode materials also exhibited a capacity of about $160 \mathrm{mAh} / \mathrm{g}$ with a retention rate of $93 \sim 96 \%$ after 100 cycles.
\end{abstract}

Keywords: Scrap recycling, Lithium ion battery, Cathode, Precursor, Recycled transition metal

\section{1. 서 론}

리튬이온전지의 상용화 이래 지금까지 가장 널리 사용 되어 온 양극소재는 리튬코발트산화물 $\left(\mathrm{LiCoO}_{2}\right)$ 이었으나 코발트는 매장량이 부족하고 지역적으로 편재되어 있어, 가격이 비싸고 가격 등락이 심한 원료이므로 최근 $\mathrm{LiCoO}_{2}$ 를 대체할 수 있는 새로운 소재로서 $\mathrm{Li}\left[\mathrm{Ni}_{1-\mathrm{x}-\mathrm{y}} \mathrm{Co}_{\mathrm{x}} \mathrm{Mn}_{\mathrm{y}}\right] \mathrm{O}_{2}$ 의 형태를 갖고 있는 이른바 '3원계' 소재 ( $\mathrm{NCM}$ )가 점차 시 장 점유율을 확대해 나가고 있다. 니켈과 망간의 가격이 코발트에 비해 상대적으로 저렴하고 전이금속 간의 조성 에 따라 양극재의 성능을 제어하는 것이 가능하므로 3 원 계 소재에 대한 관심이 점차 증대되고 있는데[1-3] 업체 간 리튬이온전지의 가격경쟁이 심화되면서 재생소재에 대 한 관심도 함께 증가하고 있는 상황이다. 또한 리튬이온전
지의 새로운 차세대 시장을 주목받고 있는 전기자동차 (EV) 또는 전력저장시스템(ESS) 등 중대형 전지의 경우, 대량의 전극소재를 사용하므로 전지에 대한 원가부담이 가중되고 또한 폐전지 발생으로 인한 심각한 환경문제를 초래한다. 이러한 상황과 맞물려서, 폐전지로부터 회수한 전이금속을 원료로 한 양극재에 대한 연구가 활발히 진행 되고 있는데 다양한 방법으로 코발트를 추출하여 $\mathrm{LiCoO}_{2}$ 를 합성하는 공정에 대한 연구가 폭넓게 수행되어 왔다[4-7]. 그 러나 아직까지 3원계 폐전지 스크랩으로부터 코발트, 니켈, 망간에 대한 전체 회수 및 이를 이용한 동일 조성의 3원계 양극재 제조에 대한 연구는 희귀한 실정이다[8-9]. 최근, 3원 계 소재 중 회수한 원료로부터 합성된 $\mathrm{Li}\left[\mathrm{Ni}_{1 / 3} \mathrm{Mn}_{1 / 3} \mathrm{Co}_{1 / 3}\right] \mathrm{O}_{2}$ 의 특성에 대한 연구가 Weng 등에 의해 보고된 바 있는데 상기 연구들은 대부분 폐전지 스크랩을 직접 산 용액에

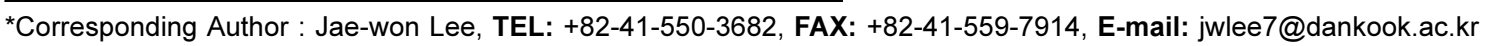


녹인 후 특정 추출용매를 사용하여 원하는 전이금속을 회 수하는 방법을 사용하였다[9].

이전 연구에서 우리는 3 원계 폐전지 스크랩으로부터 환 원 소성 전처리 공정을 이용하여 니켈과 망간, 코발트를 추출하는데 성공한 바 있다[10-11]. 환원공정은 수소를 이 용하는 방법과 탄소를 이용하는 공정으로 나눌 수 있는데 이 공정의 장점으로는 환원 소성 전처리 공정을 통해 양 극재에 포함된 리튬을 미리 회수할 수 있고 니켈, 망간, 코 발트 등 전이금속의 침출율을 $99 \%$ 까지 향상시킬 수 있으 며 리튬 회수시 탄산나트륨을 사용하지 않으므로 나트륨 불순물 함량을 줄일 수 있다는 점을 들 수 있다. 폐 양극 재 분말과 탄소를 혼합하여 비활성 분위기에서 열처리하 면 리튬은 탄소와 반응하여 $\mathrm{Li}_{2} \mathrm{CO}_{3}$ 로 전환되어 분리가 가 능하며 나머지 전이금속은 수세하여 분리가 가능하다. 또 한 수소를 사용하는 공정보다 탄소를 사용하는 공정이 공 정의 안전성이나 리튬화합물 분리의 용이성 측면에서 유 리하다.

본 연구에서는 상기 연구를 통해 폐전지에 포함된 $\mathrm{Li}\left[\mathrm{Ni}_{0.5} \mathrm{Mn}_{0.3} \mathrm{Co}_{0.2}\right] \mathrm{O}_{2}$ 양극으로부터 회수한 전이금속 추출 용액을 이용하여 동일한 조성을 갖고 있는 리튬이온전지 양극재를 다시 제조하고 특성 및 성능을 평가하여 재생 전이금속 용액의 활용 가능성을 살펴보고자 하였다. 아울 러, 환원소성법을 거쳐 회수한 재생 전이금속 용액의 특성 이 양극재의 특성에 미치는 영향을 알아보고자 한다.

\section{2. 실험방법}

\section{1. 소재 합성}

폐전지 스크랩으로부터 탄소 및 수소 환원법을 이용하 여 회수한 두 가지 전이금속 용액을 이용하여 리튬이온전지 양극재의 전구체를 합성하였다. 사용된 전이금속 용액에 포 함된 원소들의 조성은 표 1 과 같다. 여기서, 용액 $\mathrm{A}$ 는 탄소 환원 전처리 공정을, 용액 $\mathrm{B}$ 는 수소환원 전처리 공정을 이 용하여 회수한 전이금속 용액을 나타낸다. 용액 $\mathrm{A}$ 에 존재하 는 전이금속의 전체농도 및 몰 비율은 각각 $1.17 \mathrm{M}$, $\mathrm{Ni}: \mathrm{Mn}: \mathrm{Co}=52.0: 28.3: 19.7$, 용액 $\mathrm{B}$ 에 존재하는 전이금속의 전 체농도 및 몰비율은 $1.22 \mathrm{M}, \mathrm{Ni}: \mathrm{Mn}: \mathrm{Co}=53.0: 27.5: 19.5$ 에 해 당하므로 매우 유사한 조성을 갖고 있다.

Table 1. Compositions of the recycled transition metal solutions

\begin{tabular}{cccccc}
\hline \hline & \multicolumn{5}{c}{ Concentration $(\mathrm{mg} / \mathrm{L})$} \\
\cline { 2 - 6 } & $\mathrm{Ni}$ & $\mathrm{Mn}$ & $\mathrm{Co}$ & $\mathrm{Li}$ & $\mathrm{Al}$ \\
\hline Sol A & 35690 & 18160 & 13550 & 1998 & $\mathrm{~N} / \mathrm{D}$ \\
Sol B & 38810 & 18880 & 14310 & 20 & 244 \\
\hline (N/D: Not Detected) & \multicolumn{5}{c}{}
\end{tabular}

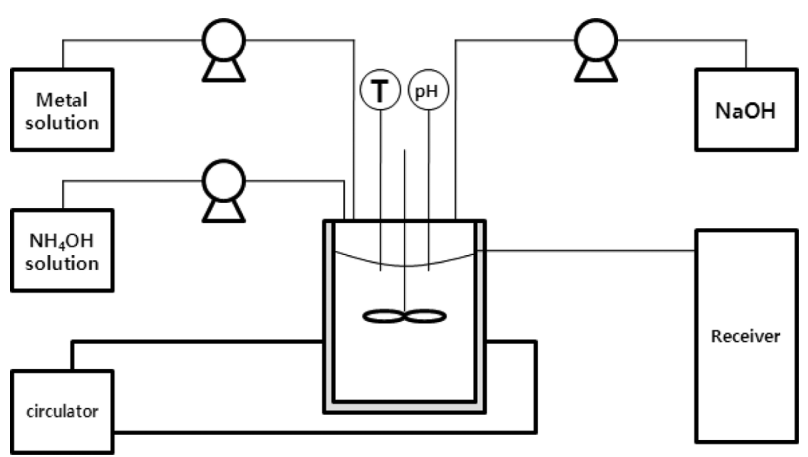

Fig. 1. Schematic diagram of the co-precipitation process.

그림 1 에 전구체 공침공정에 대한 개략도를 나타내었다. CSTR(continuous stirred tank reactor) 형태의 $1 \mathrm{~L}$ 용량 공 침반응기를 이용하였고 반응기 내부에 존재하는 전이금속 이온들의 착물형성 및 안정화를 위해 $28 \mathrm{wt} \%$ 암모니아 수용액(JUNSEI, $28 \mathrm{wt} \%$ )을 사용하였다. 반응기 내부의 온도는 순환조(circulator)와 반응기 외부의 자켓(jacket)을 이용하여 제어하였고 수산화나트륨(SAMCHUN, 98\%) 25 $\mathrm{wt} \%$ 수용액을 이용하여 $\mathrm{pH}$ 를 조절하였다. 반응기 내부에 는 배플(baffle)을 설치하여 반응물이 균질하게 혼합되도 록 하였다.

자동제어를 통해 반응이 이루어지는 동안 온도와 $\mathrm{pH}$ 가 설정값(온도: $\left.45^{\circ} \mathrm{C}, \mathrm{pH}: 11.5\right)$ 을 유지하도록 하였고 전이 금속과 암모니아의 비율은 $1: 1$ 몰비를 유지하였다. 상기 $\mathrm{pH}$, 온도 및 전이금속과 암모니아 비율 등 반응조건은 유 사한 조성에서 시약급 원료를 사용하여 수행한 연구로부 터 결정된 최적조건이다. 반응기 내부의 반응물 체류시간 $(\tau)$ 은 8 시간으로 설정하여 전이금속 용액과 암모니아 용액 의 유량을 설정하였고 수산화나트륨 용액은 $\mathrm{pH}$ 설정치에 맞추어 자동으로 적하되었다. 반응 후, 합성된 전구체는 수세, 여과 및 건조과정을 거쳐 분말형태로 얻었다.

상기 방법을 통해 제조한 전구체를 이용하여 양극재를 합성하였는데 탄산리튬 $\left(\mathrm{Li}_{2} \mathrm{CO}_{3}\right)$ 과 전구체를 화학양론비에 맞추어 리튬:전이금속 $=1: 1$ 몰비로 균질하게 혼합하여 전 기로 내에서 고상법을 통해 합성하였다. 합성 온도는 $900^{\circ} \mathrm{C}$ 에서 10 시간 동안 유지하여 공기 분위기에서 양극재 를 제조하였다.

\section{2. 소재 물성평가}

제조한 전구체와 양극재는 X선 회절분석법(XRD, Rigaku, Ultima IV)을 통하여 결정상 분석을 실시하였고 입자의 형 상은 광학현미경과 전자주사현미경(SEM, TESCAN, MIRA $\mathrm{LMH})$ 을 이용하여 분석하였다. $\mathrm{XRD}$ 분석은 $\mathrm{Cu}-\mathrm{K} \alpha$ 선을 이용하였으며 $2 \theta=5 \sim 80^{\circ}$ 까지 분석하였다.

양극재의 성능평가를 위해 코인형 전지(CR2016)를 제 
조하여 용량, 율특성 및 수명특성을 분석하였다. 전극제조 를 위해 양극재:바인더 $(\mathrm{PVdF})$ :도전재 $(\mathrm{SuperP})=88: 8: 4$ 의 중량비로 NMP(N-methyl pyrrolidone)에 넣고 혼합하여 슬 러리를 만들고 이를 알루미늄 호일위에 도포하여 닥터블 레이드로 코팅하였다. 이후, $120^{\circ} \mathrm{C}$ 에서 8 시간 동안 진공 건조하여 수분을 제거하고 롤 프레스기를 이용하여 압연 한 후 적절한 크기의 디스크 형태로 타발하여 전극으로 사용하였다. 반대전극 및 보조전극으로는 리튬 호일을 사 용하였고 전해질은 $\mathrm{EC}: \mathrm{EMC}=1: 2 \mathrm{vol} \%$ 의 용매에 $\mathrm{LiPF}_{6}$ 를 $1.0 \mathrm{M}$ 의 농도로 녹여 사용하였다. 제작된 셀은 $25^{\circ} \mathrm{C}$ 항온 박스에서 PNE Solution사의 충방전기(모델명 PEBC050.1) 를 이용하여 전기화학적 특성을 평가하였다. 수명특성 평 가는 충방전전류속도를 초기 네 사이클은 $0.1,0.2,0.5,1$ C-rate 로 변화시켜 측정하였으며, 마지막에는 $1 \mathrm{C}$-rate 충 방전을 100 회 진행하였다. 율특성 평가는 충전전류 $0.5 \mathrm{C}$ rate로 고정 후 방전 전류를 $0.2,0.5,1,3,5,7$ C-rate로 변화시켜 가면서 측정하였다. 충·방전 시 cut-off는 $3 \sim 4.3$ $\mathrm{V}\left(\mathrm{vs} \mathrm{Li} / \mathrm{Li}^{+}\right)$까지 수행하였다.

\section{3. 결과 및 고찰}

\section{1. 전구체 및 양극재의 물리화학적 특성}

폐전지 스크랩으로부터 두 가지 조성의 전이금속 황산 염 수용액을 제조하고, 이를 이용하여 리튬이온전지 양극 재용 전구체를 합성하였다. 표 1 에 수록한 실험에 사용한 두 가지 조성의 용액(용액 $\mathrm{A}$ 와 용액 $\mathrm{B})$ 의 경우 $\mathrm{Ni}: \mathrm{Mn}$ : $\mathrm{Co}$ 의 비율은 각각, $0.52: 0.28: 0.20,0.53: 0.28: 0.19$ 로 거의 유사한 조성을 갖는다. 따라서, 각 용액으로부터 제조한 전구체 및 양극재의 특성 차이는 리튬 및 알루미늄 불순 물로부터 기인하는 것으로 간주하고 연구를 수행하였다. 위의 조성은 몰농도로 환산할 경우 전이금속의 총농도의 합이 $1.17 \mathrm{M}, 1.22 \mathrm{M}$ 에 해당한다.

상기 회수 전이금속 용액들을 이용하여 공침법을 통해 제조한 전구체 입자의 형상을 그림 2에 나타내었다.

공침반응 시, CSTR에 체류하는 시간 $(\tau)$ 을 8시간으로 설 정하고 이에 맞추어 전이금속 용액, 암모니아 수용액의 유 량을 조절하였다. 또한 $\mathrm{pH}=11.0$ 에 맞추어 수산화나트륨 용액이 자동 투입되도록 설정하였다. 원료를 투입하기 시 작하여 40 시간 후에 전구체 샘플을 채취하여 광학현미경 으로 입자의 성장 상태를 확인하였다(그림 2(a), (b)).

위의 그림에서 보이듯이 두 샘플 모두 $10 \mu \mathrm{m}$ 내외의 입 자 크기를 보이고 있으며 $\mathrm{A}$ 용액에 비하여 용액 $\mathrm{B}$ 로부터 제조된 전구체의 입자가 약간 더 크고 성장이 많이 이루 어진 것을 알 수 있다. 그러나, 두 경우 모두 입자의 크기 가 균일하여 미세입자나 조대입자가 거의 관찰되지 않았

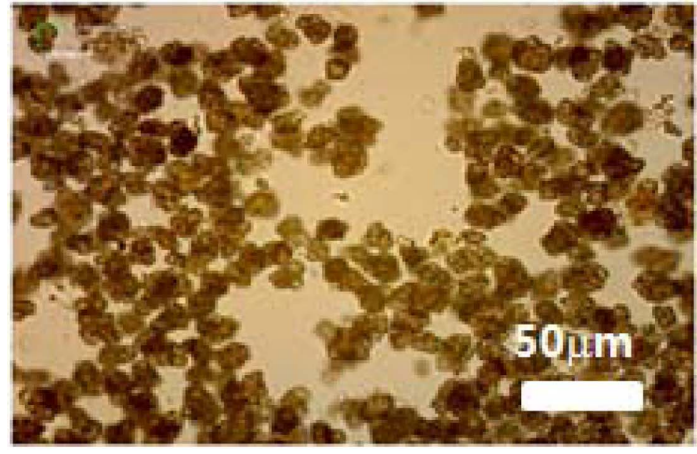

(a)

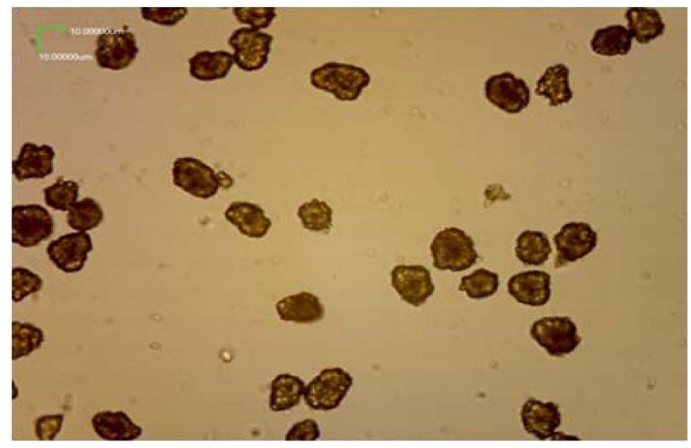

(b)

Fig. 2. Morphology and size of the precursor particles prepared with (a) solution $A$ and (b) solution $B$.

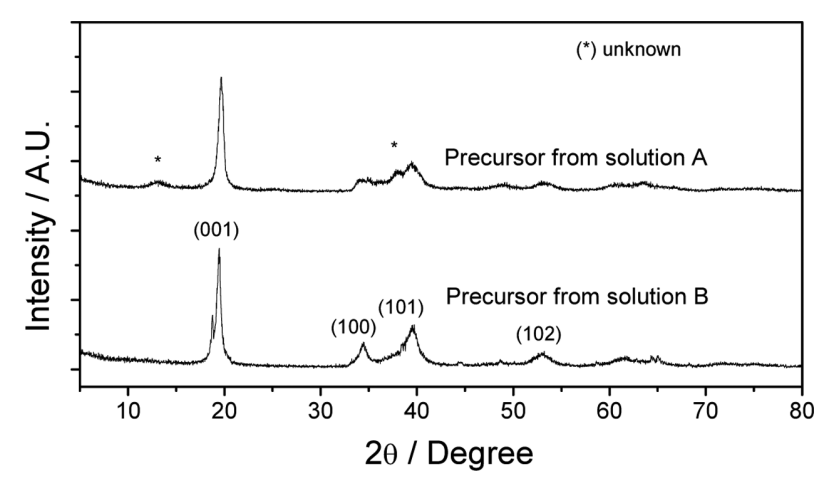

Fig. 3. XRD patterns of the precursors prepared from solution $A$ and $B$.

다. 입도분석결과, $\mathrm{A}, \mathrm{B}$ 용액으로부터 합성한 전구체의 $\mathrm{D} 50$ 은 각각 $11.8,14.0 \mu \mathrm{m}$ 수준이었다. 합성온도, 교반속 도, $\mathrm{pH}$, 유량 등 다른 모든 합성조건이 동일하고 두 가지 용액의 농도 또한 $0.05 \mathrm{M}$ 수준의 적은 농도차를 보이고 있으므로 상기 인자들의 영향이 무시할 만한 수준임을 고 려할 때, 알루미늄 불순물의 존재가 전구체 입자의 성장에 제약조건으로 작용하지 않은 것으로 보이며, 리튬 불순물 은 다소 전구체 입자의 성장을 방해하는 작용을 한 것으 로 추정된다.

그림 3 은 회수 전이금속 용액으로부터 제조한 전구체의 결정상을 분석한 XRD 패턴이다. 공침 후 얻은 전구체들 


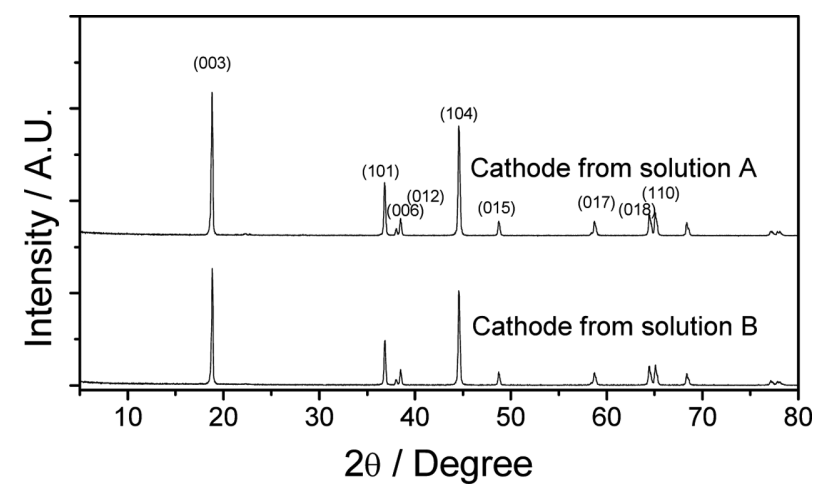

Fig. 4. XRD patterns of the cathode materials prepared from solution $A$ and $B$.

은 두 용액 모두 주 결정상은 $\beta-\mathrm{Ni}(\mathrm{OH})_{2}$ (JCPDS file No. 14-0117)의 기본 결정구조를 갖고 있으며 코발트와 망간 의 일부 치환에 따른 피크의 넓어짐(peak broadening)이 관찰되며 피크의 약한 강도로 볼 때, 결정성이 낮은 것으 로 판단된다. 용액 $\mathrm{A}$ 로부터 제조한 전구체의 경우 미량의 불순물이 존재하는 것으로 관찰되었다.

위 두 가지 전구체와 $\mathrm{Li}_{2} \mathrm{CO}_{3}$ 를 함께 혼합하고 열처리하 여 얻은 양극재에 대한 결정구조를 그림 4에 나타내었다.

$\mathrm{XRD}$ 분석결과에서 보는 바와 같이 두 가지 양극재 모 두 $\alpha-\mathrm{NaFeO}_{2}$ 타입의 전형적인 층상구조를 보이고 있다. 다른 결정상의 불순물은 발견되지 않으며 두 샘플 모두 높은 결정성을 나타낸다. 일반적으로 상대적인 피크의 강 도 $\mathrm{R}=\left(\begin{array}{lll}0 & 0 & 3\end{array}\right) /\left(\begin{array}{lll}1 & 0 & 4\end{array}\right)$ 의 크기로부터 리틈 자리(3a)와 전이 금속 자리(3b) 사이의 부분적인 상호치환(cation mixing)의 정도를 알 수 있는데 $\mathrm{R}$ 값이 1.2보다 작은 경우 cation mixing에 의한 전기화학적인 물성저하가 있는 것으로 알 려져 있다. ${ }^{12)}$ 본 연구에서 회수 용액으로부터 얻은 양극재 는 용액 $\mathrm{A}$ 와 $\mathrm{B}$ 로부터 제조한 샘플이 각각 $\mathrm{R}=1.08,0.95$ 의 값을 보여 cation mixing의 영향에 의한 성능저하가 다소 존재할 것으로 예상된다. 그러나 $\left(\begin{array}{lll}0 & 0 & 6\end{array}\right),\left(\begin{array}{lll}1 & 0 & 2\end{array}\right)$ 피크의 분리, (llll), (1 10 1 10 ) 피크의 분리가 확연하여 잘 발달된 층상구조를 갖고 있는 것으로 판단된다.

리튬이온전지의 양극재는 결정구조와 순도 뿐 아니라 입자의 형상이나 입도분포가 매우 중요한데 전극 단위부 피당 높은 에너지를 저장하기 위해서는 입자간의 높은 충 진도가 필요하므로 일반적으로 둥근 모양의 입자가 바람 직하다. 본 연구에서 제조한 양극재 입자에 대한 전자현미 경 사진을 그림 5 에 나타내었다.

그림 5에서 보듯이 양극재 입자의 형태와 크기는 전구 체 입자의 모폴로지를 거의 유지하는 것으로 관찰되었고 용액 $\mathrm{B}$ 로부터 제조한 양극재가 약간 더 큰 입도를 보이는 것으로 나타났다. 입도분석결과, $\mathrm{A}, \mathrm{B}$ 용액으로부터 제조한 양극재의 $\mathrm{D} 50$ 은 각각 $12.1,14.3 \mu \mathrm{m}$ 수준의 입자크기를 보

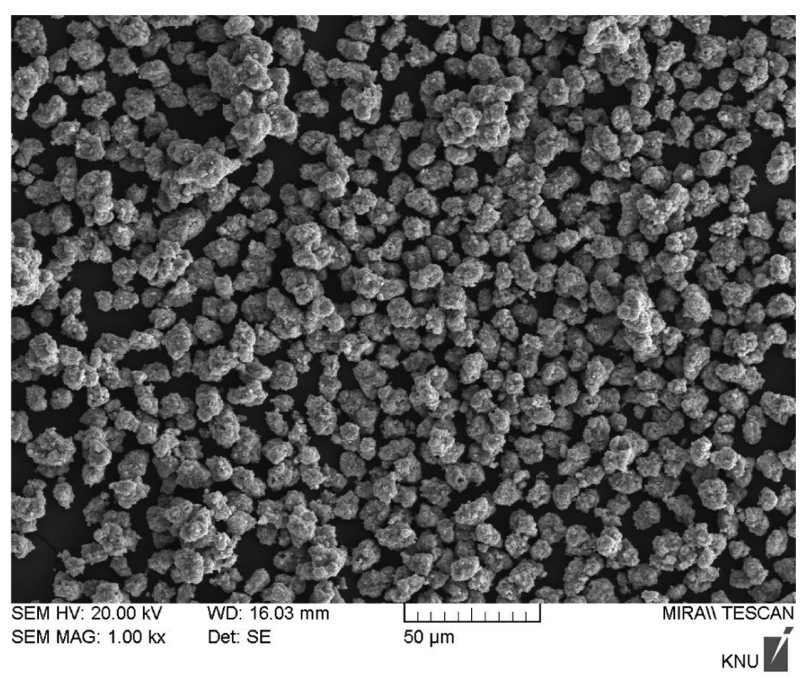

(a)

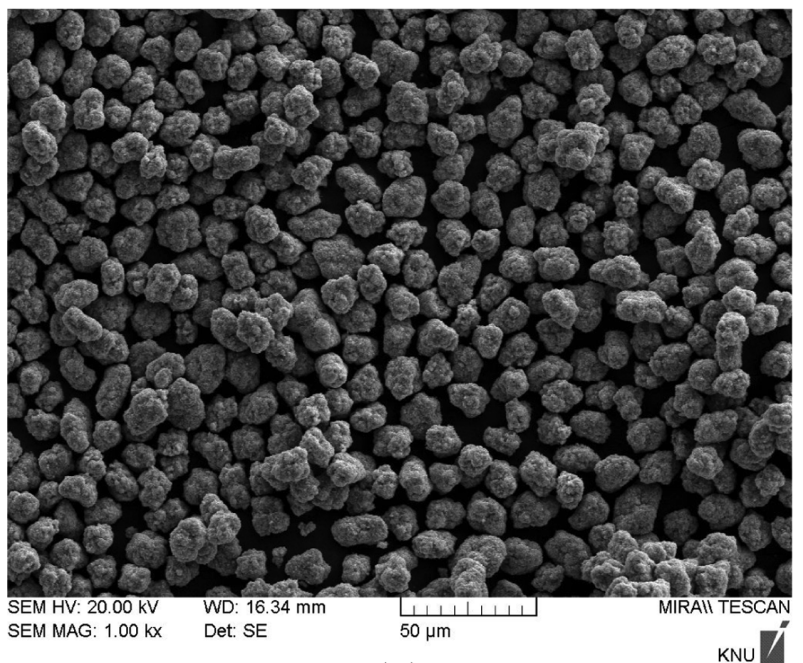

(b)

Fig. 5. SEM images of the cathode materials prepared with (a) solution $A$ and (b) solution $B$.

여 전구체의 입자크기에 비해 모두 커진 것으로 나타났다.

\section{2. 전구체 및 양극재의 전기화학적 특성}

두 가지 양극재를 이용하여 전극을 제조하고 리튬이온 전지로서의 성능을 평가하였다. $0.2 \mathrm{C}$-rate에서 충방전 용 량과 전류밀도 증가에 따른 방전용량의 변화(율특성) 및 $1 \mathrm{C}$-rate에서의 충방전 수명특성을 조사하였으며 그 결과는 그림 6과 7에 나타내었다. 그림 6에 나타난 바와 같이 용 액 $\mathrm{A}$ 와 $\mathrm{B}$ 로부터 제조된 양극재가 각각 약 $161 \mathrm{mAh} / \mathrm{g}$, $158 \mathrm{mAh} / \mathrm{g}$ 의 값을 나타내었다. 큰 용량차이를 보이지는 않으나 용액 B로부터 얻은 양극재의 용량이 다소 낮은 이 유는 미량의 알루미늄 불순물의 영향이라고 생각된다. 일 반적으로 공침 용액에 포함되어 있는 리틈이온은 전이금 속 수산화물 형성과정에서 격자 내에 포함되지 않고 추후 


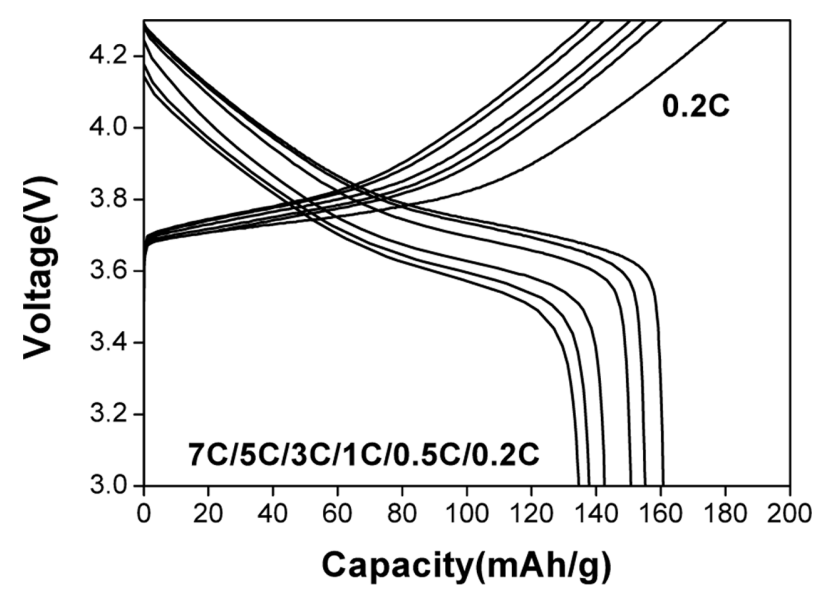

(a)

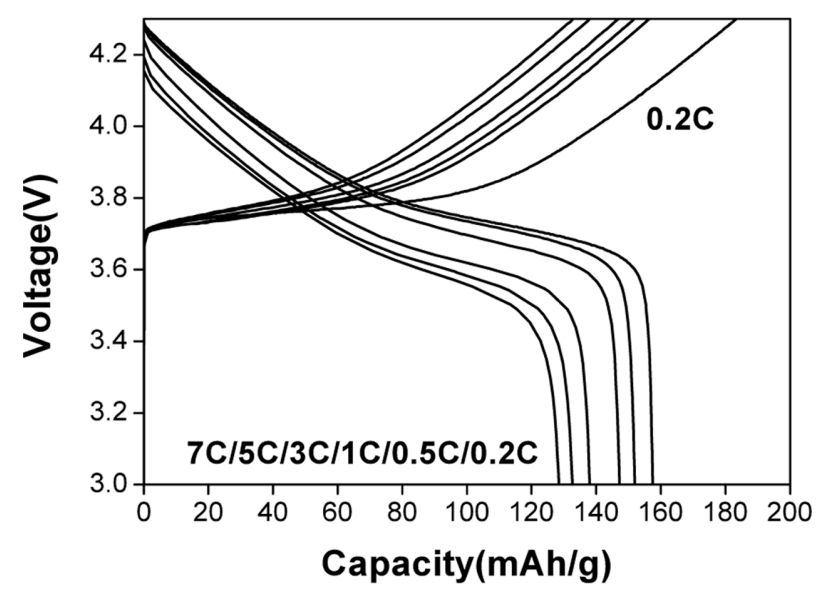

(b)

Fig. 6. Rate capabilities of the cathode materials prepared with (a) solution $A$ and (b) solution $B$.

에 수세과정을 통해 제거되지만 알루미늄 이온의 경우에 는 전구체의 전이금속 자리에 일부 치환되는 현상을 나타 낸다. 따라서, 용액 B를 이용하여 얻은 양극재에는 알루미 늄 미량이 전이금속 자리에 치환되어 있을 것으로 예상되 며 이러한 이유로 인해 전이금속의 산화수 및 함량에 영 향을 미쳐 방전용량의 감소를 가져왔을 가능성이 있다.

또한, 충전시 전류밀도를 $0.2 \mathrm{C}$-rate으로 고정하고 방전 전류밀도를 변화시켜 가면서 용량 변화를 측정하였다. 그 결과, $\mathrm{A}$ 용액으로부터 제조한 양극재의 경우 7 C-rate에서 의 방전용량이 0.2 C-rate 대비 $87 \%$ 수준을 유지하였다. 반면, B용액으로부터 제조한 양극재는 그 보다 $3 \%$ 가량 낮은 용량 유지율을 보여 $\mathrm{A}$ 용액에 비해 다소 낮은 율특성 을 나타내었다. 그 이유로는 $\mathrm{A}$ 용액으로부터 제조한 양극 재의 입자가 상대적으로 작기 때문에 전해액과의 전기화 학반응을 위한 보다 넓은 접촉면적을 제공함과 동시에, 양 극재의 입자가 작아 리튬이온의 확산거리가 짧아졌기 때 문이라고 생각된다.

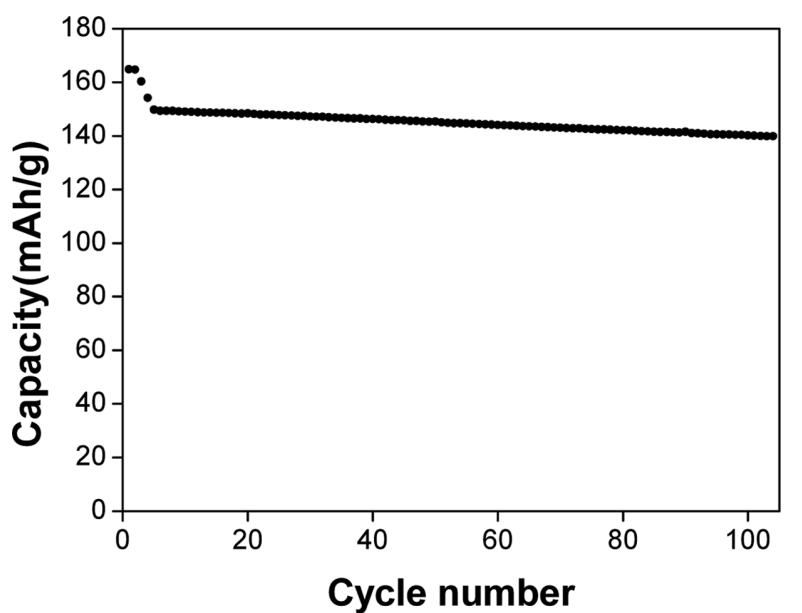

(a)

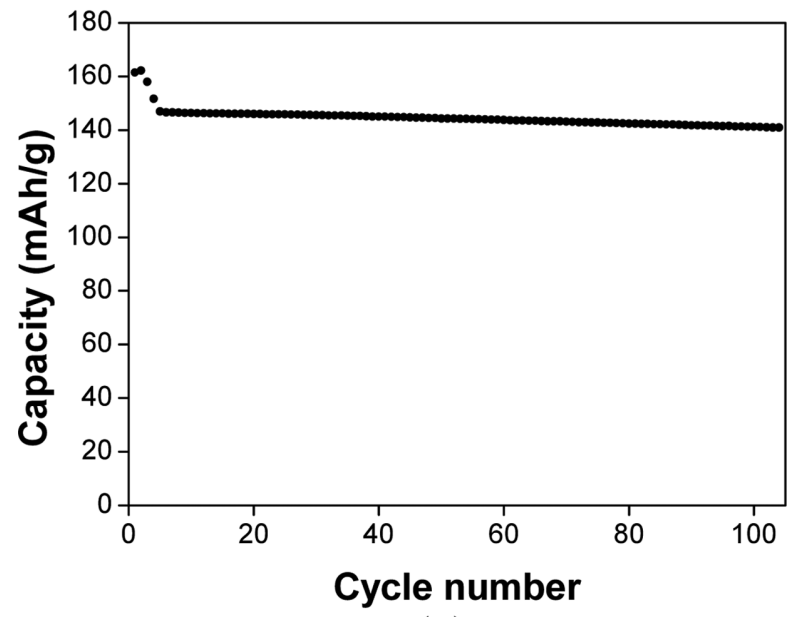

(b)

Fig. 7. Cycle life performances of the cathode materials prepared with (a) solution $A$ and (b) solution $B$.

그림 7은 두 가지 양극재의 수명특성 평가결과를 나타 낸다. 그림 중 검은색 점은 방전용량을 나타낸다. 충방전 절차는 우선 $0.1 \mathrm{C}$-rate로 충방전을 2회 실시하고 $0.2 \mathrm{C}$ rate로 1회, 0.5 C-rate로 1회 실시한 후 $1 \mathrm{C}$-rate로 95회 수 행하였다. 이 때, $1 \mathrm{C}$-rate로 충방전한 초기와 최종 사이클 의 방전용량을 비교하면 용액 $\mathrm{A}$ 와 $\mathrm{B}$ 로부터 얻은 양극재 는 각각 $93.4 \%$ 와 $95.9 \%$ 의 용량유지율을 보인다. 일반적 으로, 양극재의 입자가 작은 경우에는 전해액과의 접촉면 적이 커지기 때문에 충방전 과정 중 발생할 수 있는 전극 과 전해액 간의 부반응이 늘어나므로 수명특성이 낮아지 게 되는 경우가 많은데 그 이유는 전극과 전해액의 부반 응이 클 경우, 리튬이온의 부반응 참여에 따른 소모와 반 응 부산물의 전극 침착으로 인한 저항증가가 일어나기 때 문이다. 본 연구에서 합성한 양극재 역시 이러한 경향에 따라 입자의 크기가 상대적으로 큰, 용액 $\mathrm{B}$ 로부터 제조한 양극재가 보다 우수한 용량 유지율을 나타내었다. 
종합적으로, 폐전지 스크랩으로부터 얻은 회수 전이금 속 용액을 이용하여 합성한 리튬이온전지 양극재는 용량, 율특성 및 수명특성 등 기본적인 성능에서 양호한 특성을 보이는 것으로 평가되었고 보다 정밀한 시험을 위해서는 완전지(full-cell) 수준에서의 심층적인 검증이 필요할 것으 로 예상된다.

\section{4. 결 론}

폐전지 스크랩으로부터 회수한 전이금속 원료의 이차전 지 소재 원료로서의 재활용 가능성을 알아보기 위한 실험 을 수행하여 다음과 같은 결론을 얻어 내었다.

1) 동일한 조성을 갖고 있는 회수 원료를 이용하여 전구 체와 양극재를 합성한 결과, $10 \mu \mathrm{m}$ 수준의 입자 크기를 보였으며 $160 \mathrm{mAh} / \mathrm{g}$ 수준의 방전용량과 우수한 수명특성 을 얻을 수 있었다.

2) 리튬 불순물이 포함된 회수 용액의 경우, 그렇지 않은 대조 원료에 비해 전구체 합성시 입자의 크기가 다소 작고 결정성도 다소 떨어지는 모습을 보였는데 이는 원료 용액에 존재하는 리튬이온이 공침 공정에서 전구체 입자의 성장을 방해하는 역할을 하는 것으로 추정된다. 따라서, 회수 용액 을 전구체 합성에 이용할 경우, 용액 내에 존재하는 리튬이 온을 제거할 수 있는 공정이 필요할 것으로 사료된다.

3) 일반적으로 폐전지 스크랩에 다량 포함되어 있는 알 루미늄의 경우 회수 전이금속 용액에 미량 포함되어 있는 경우라 하더라도 전구체 및 양극재의 물리화학적 혹은 전 기화학적 특성에 큰 영향을 미치지 않는 것으로 판단된다.

4) $\mathrm{A}$ 용액과 B용액으로부터 제조한 양극재의 특성을 비 교한 결과, $\mathrm{A}$ 용액의 경우 용액 내에 존재하는 리튬이온의 영향으로 인해 입자크기가 작아 율특성은 $\mathrm{B}$ 용액으로 제조 한 양극재에 비해 $3 \%$ 가량 높으나 수명특성이 떨어지는
현상을 나타내었고 용액 $\mathrm{B}$ 의 경우 미량 존재하는 알루미 늄 이온의 영향으로 인해 방전용량이 다소 줄어드는 현상 이 관찰되는 것으로 추정된다.

\section{감사의 글}

본 연구는 중소기업청에서 시행하는 2012년도 중소기업 기술개발지원사업 기술혁신개발사업에 의하여 "리튬이온 전지 스크랩을 원료로 한 $\mathrm{NCM}$ 전구체 및 고순도 리튬화 합물 제조기술개발"에 관한 일련의 연구로 수행되었으며, 이에 감사드립니다(과제번호 S2045890).

\section{참고문헌}

[1] M. S. Whittingham: Chem. Rev., 104 (2004) 4271.

[2] J. W. Fergus: J. Power Sources, 195 (2010) 939.

[3] B. Xu, D. Qian, Z. Wang and Y. S. Meng: Mater. Sci. Eng. R, 73 (2012) 51.

[4] J. W. Ahn and H. J. Ahn: J. Kor. Inst. of Res. Recycling, 20 (2011) 65.

[5] J. J. Lee and J. D. Chung: J. Kor. Inst. of Res. Recycling, 19 (2010) 51.

[6] B. Swain, J. Jeong, M. S. Kim, J. C. Lee and J. S. Sohn: J. Kor. Inst. Resources Recycling, 14 (2005) 28.

[7] C. K. Lee and K. I. Rhee: J. Power Sources, 109 (2002) 17.

[8] C. Liang et al.: The Chinese J. of Nonferrous Metals, 21 (2011) 1192.

[9] Y. Weng, S. Xu, G. Huang and C. Jiang: J. Hazardous Mater., 246-247 (2013) 163.

[10] D. W. Kim, S. T. Jang and K. M. Baek: J. Kor. Inst. of Res. Recycling, 22 (2013) 43 (Korean).

[11] D. W. Kim and S. T. Jang: J. Kor. Inst. of Res. Recycling, 22 (2013) 62 (Korean).

[12] K. M. Shaju, G. V. Subba Rao and B. V. R. Chowdari: Electrochim. Acta, 48 (2002) 145. 